\title{
Growth and Spread of the Argentine Black and White Tegu Population in Florida ${ }^{1}$
}

\author{
Rebecca G. Harvey, Justin R. Dalaba, Jenny Ketterlin, Art Roybal, Daniel Quinn, and Frank J. \\ Mazzotti $^{2}$
}

\section{Florida's Reptilian Invasion}

The accumulation of exotic reptiles and amphibians in Florida has been called a "runaway train" that has yet to be controlled (Meshaka 2011). Based on twenty years of field work and an examination of museum records and literature, no other place in the world ranks as having a higher number of introduced reptile and amphibian species than the state of Florida. Of 63 established exotic reptilian and amphibian species, 48 are lizards (Krysko et al. 2016). South Florida is especially at risk because of its subtropical climate, large areas of disturbed habitats, and thriving trade in exotic pets. Although pythons receive the majority of public attention, large invasive lizards also pose a significant threat to south Florida's native wildlife and ecosystems.

The Argentine black and white tegu (Salvator merianae, formerly Tupinambis merianae; Harvey et al. 2012) was introduced to Florida through the pet trade and has established breeding populations in Hillsborough and Miami-Dade counties (Pernas et al. 2012). The Florida Fish and Wildlife Conservation Commission (FWC) has been coordinating efforts to manage another breeding population in Charlotte County and an emerging population in St. Lucie County.
The Argentine black and white tegu (tegu) is one of the largest lizard species in the Western Hemisphere, growing up to four feet in total length (Figure 1). Females lay an average of 35 eggs per year starting at age three or four. Tegus have survived below-freezing temperatures in Florida by burrowing during the winter months (McEachern et al. 2015). The tegu's broad habitat use and omnivorous diet create the potential for severe ecological impacts.

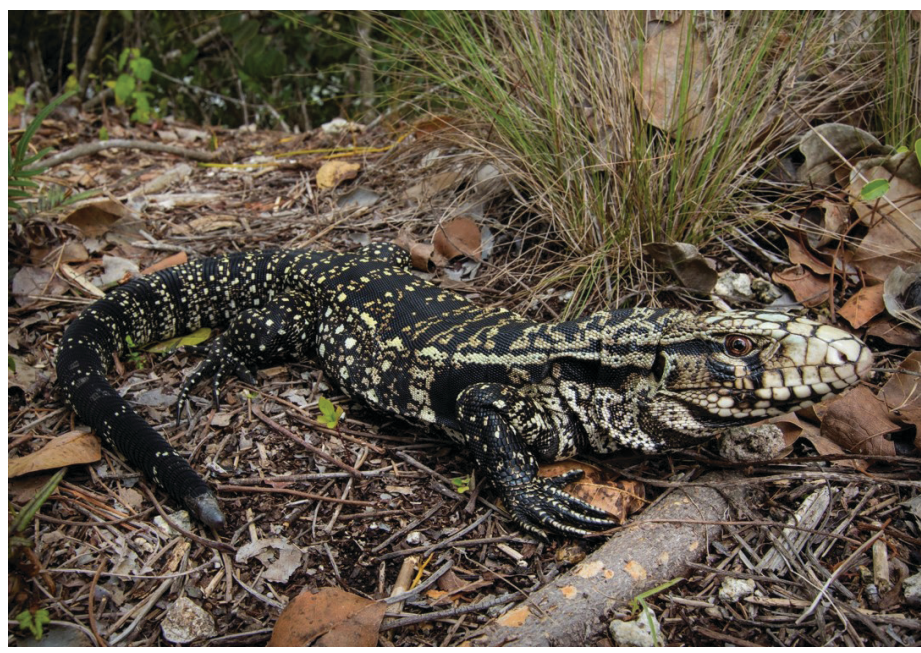

Figure 1. Adult Argentine black and white tegu (Salvator merianae). Credits: Nick Scobel, UF/IFAS

1. This document is WEC437, one of a series of the Department of Wildlife Ecology and Conservation. Original publication date November 2015; revised June 2021. Originally written by Rebecca G. Harvey, former environmental education coordinator; revised by Justin R. Dalaba. Visit the EDIS website at https://edis.ifas.ufl.edu for the currently supported version of this publication.

2. Rebecca G. Harvey, former environmental education coordinator, Department of Wildlife Ecology and Conservation; Justin R. Dalaba, science writer and outreach coordinator,Department of Wildlife Ecology and Conservation, UF/IFAS Fort Lauderdale Research and Education Center, Davie, FL 33314; Jenny Ketterlin, invasive species biologist, National Park Service, Homestead, FL 33030; Art Roybal, senior fish and wildlife biologist, U.S. Fish and Wildlife Service, Vero Beach, FL 32960; Daniel Quinn, nonnative fish and wildlife biologist, Florida Fish and Wildlife Conservation Commission, Fort Meyers, FL 33901; and Frank J. Mazzotti, professor,Department of Wildlife Ecology and Conservation, UF/IFAS Fort Lauderdale Research and Education Center, Davie, FL 33314; UF/IFAS Extension, Gainesville, FL 32611.

The Institute of Food and Agricultural Sciences (IFAS) is an Equal Opportunity Institution authorized to provide research, educational information and other services

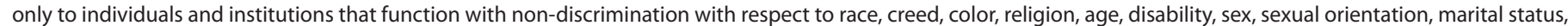

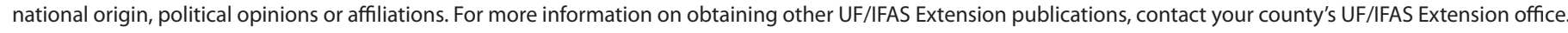
U.S. Department of Agriculture, UF/IFAS Extension Service, University of Florida, IFAS, Florida A \& M University Cooperative Extension Program, and Boards of County Commissioners Cooperating. Nick T. Place, dean for UF/IFAS Extension. 


\section{More Tegus in More Areas}

Collaborative interagency efforts to assess the south Florida tegu population through surveys, trapping, radiotracking, and removal began in 2009 within the Everglades Cooperative Invasive Species Management Area (ECISMA). Since then, Argentine black and white tegus have grown in number and expanded their range in south Florida. Tegus have now been reported in 35 Florida counties and 4 Georgia counties (EDDMapS 2020). Both the number of tegus removed and the effort expended to catch them have increased (Figure 2). These totals do not include tegus removed by private trappers, some of whom reported removing more than 400 in one year.

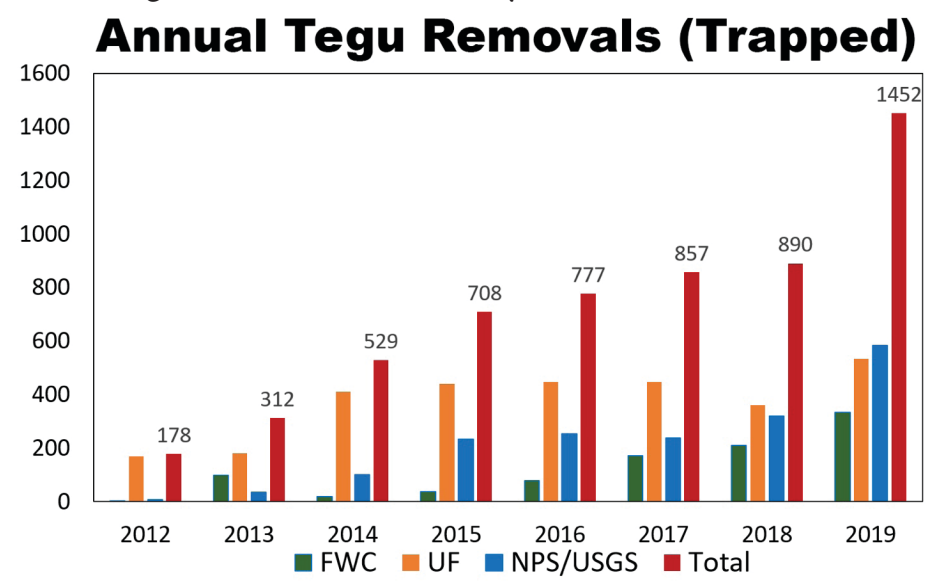

Figure 2. Tegus removed by year (2012-2019) by Florida Fish and Wild life Conservation Commission (FWC), University of Florida (UF), National Park Service (NPS) and United States Geological Survey (USGS) through trapping.

Credits: National Park Service

The south Florida tegu population is centered in Florida City and Southern Glades Wildlife and Environmental Area. Tegus are dispersing from this core area. To the east, several have been removed from the Turkey Point Power Plant site, a nesting area of federally threatened American crocodiles (Crocodylus acutus), and just outside the border of Biscayne National Park. To the west and south, they are advancing into Everglades National Park and into the Florida Keys. Levees facilitate tegus' spread into vulnerable habitats that would otherwise be isolated from terrestrial invaders (Klug et al. 2015).

With a newly emerging population of tegus in St. Lucie County and occasional sightings in Broward and Palm Beach counties, the potential for their spread is an ongoing threat on the east coast of Florida. On the west coast of Florida, there is now an established population in Charlotte County and Hillsborough County (Figure 3). Tegus are likely established in several counties in Georgia (Haro et al. 2020 ) and have proven capable of surviving winter in seminatural enclosures in Alabama (Goetz et al. 2021). These observations support predicted suitable habitat modeling which suggest the potential for tegus to expand their range north of Florida (Jarnevich et al. 2018).

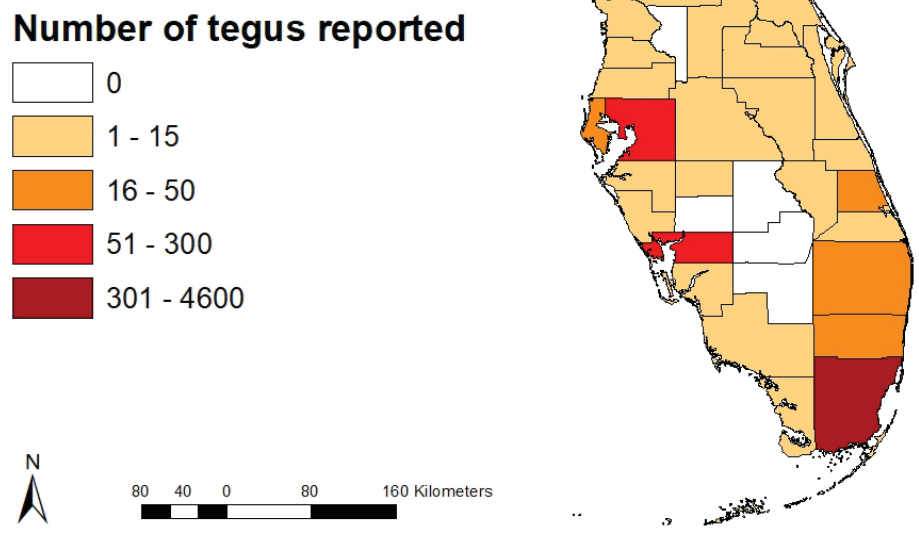

Figure 3. Number of verified Argentine black and white tegu reports to EDDMapS by Florida County through March 2020. There are established breeding populations in Hillsborough, Charlotte, MiamiDade, and St. Lucie Counties.

Credits: EDDMapS; Accessed 20 March 2020

\section{What's at Stake}

The Argentine black and white tegu is an omnivore that eats fruits, vegetables, eggs, insects, and small animals. As a predator, the tegu is likely to have harmful effects on south Florida's native wildlife.

In an analysis of 124 gut content samples from tegus captured along the urban fringe in Miami-Dade County, 39\% contained vertebrate remains. These included frogs, toads, lizards, snakes, turtles, and small mammals. The discovery of gopher tortoise (Gopherus polyphemus) hatchlings in the gut content of five tegus from central Florida confirms their threat to imperiled and protected species in Florida (Offner et al. 2021).

Tegus are especially known for eating buried eggs of reptiles and have been documented eating eggs of American alligators (Alligator mississippiensis) and turtles in Florida (Figure 4; Mazzotti et al. 2014). Camera traps have also captured photos of a tegu on an American crocodile nest. Hence, a growing and spreading tegu population may reduce populations of threatened and endangered native species such as crocodiles, sea turtles, ground-nesting birds, and the endemic Key Largo woodrat (Neotoma floridana smalli). 


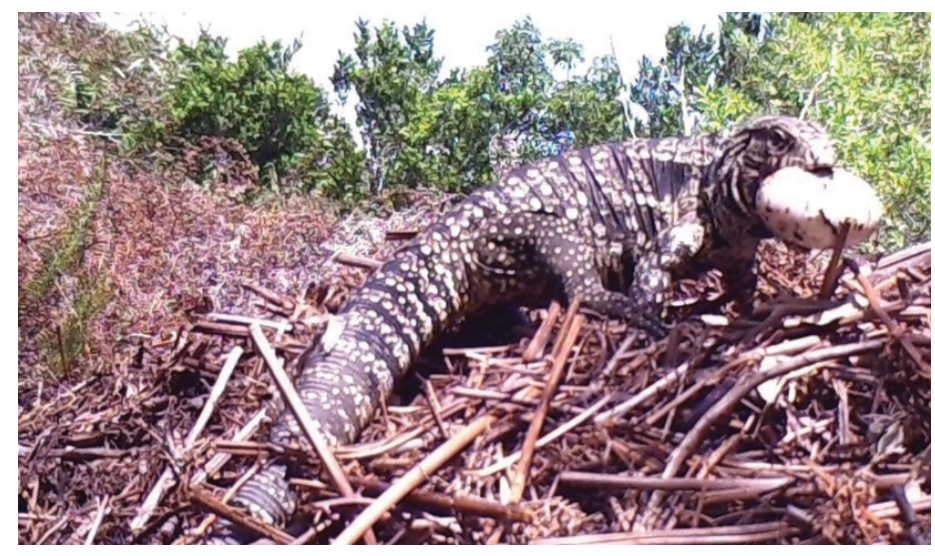

Figure 4. Argentine black and white tegu leaving an American alligator nest with an alligator egg in its mouth.

Credits: Mazzotti et al. (2014)

\section{Interagency Efforts to Reduce the Threat}

The University of Florida, the Florida Fish and Wildlife Conservation Commission, the United States Geological Survey, the United States Fish and Wildlife Service, the National Park Service, and the South Florida Water Management District have developed a cooperative program to contain and reduce the tegu population in south Florida. Program tasks include the following:

- Locate and remove tegus in the occupied area using driving and walking surveys, camera traps, and live traps.

- Prevent expansion to new areas (including both public and private lands) via live traps, camera traps, and community outreach.

- Develop and validate a new method of evaluating the impact of tegu removal on tegu populations.

- Use radio telemetry to understand how tegus move through the landscape and apply results to enhance removal of tegus.

\section{Implications of Expansion}

There is an urgent need to prevent further expansion of tegus both within and beyond Florida. Without increased management effort, tegus are likely to move beyond the "containment" phase, becoming so widespread and abundant that costly long-term management may be needed (Figure 5). It is essential to act now to halt the spread and invasion of Argentine black and white tegus, thereby preventing irreversible damage to the biological diversity and ecological integrity of Greater Everglades natural areas. Preventing the spread of tegus will be less expensive and more effective than attempting to remove an established population later.

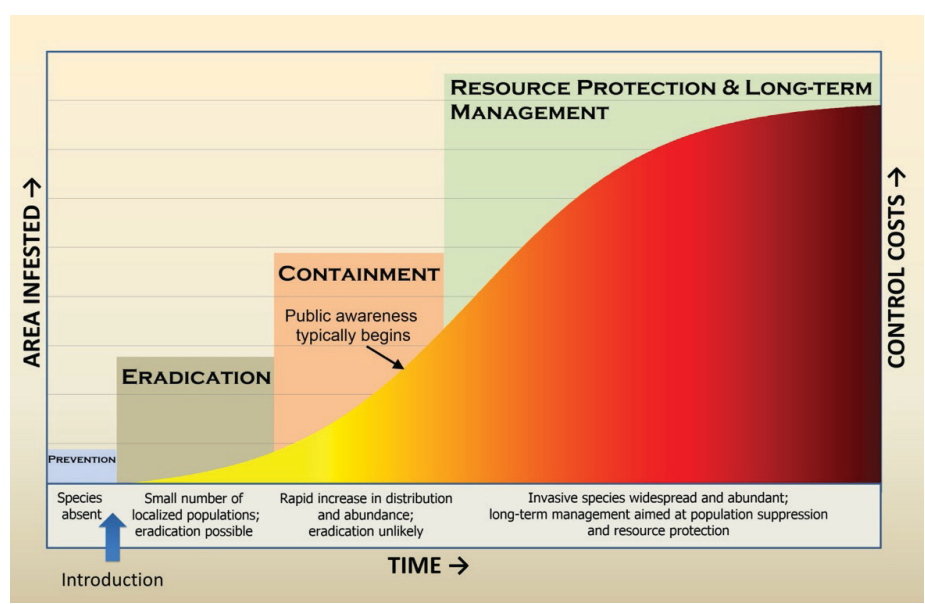

Figure 5. The Invasion Curve.

Credits: Adapted from Invasive Plants and Animals Policy Framework, State of Victoria, Australia, 2010

\section{References}

EDDMapS. 2020. Early Detection \& Distribution Mapping System. The University of Georgia - Center for Invasive Species Ecosystem Health. Available online at https://www. eddmaps.org/; last access March 20, 2020.

Goetz, S. M., D. A. Steen, M. A., Miller, C. Guyer, J. Kottwitz, J. F. Roberts, E. Blankenship, P. R. Pearson, D. A. Warner, D.A. and R. N. Reed. 2021. "Argentine Black and White Tegu (Salvator merianae) can survive the winter under semi-natural conditions well beyond their current invasive range." PloS one, 16(3), p.e0245877.

Haro, D., L. D. McBrayer, J. B. Jensen, J. M. Gillis, B. Lea'R, M. G. Nafus, S. E. Greiman, R. N. Reed, and A. A. Y. Adams. 2020. "Evidence for an Established Population of Tegu Lizards (Salvator merianae) in Southeastern Georgia, USA." Southeastern Naturalist, 19(4), pp.649-662.

Harvey, M. B., G. N. Ugueto, and R. L. Gutberlet, Jr. 2012. "Review of Teiid Morphology with a Revised Taxonomy and Phylogeny of the Teiidae (Lepidosauria: Squamata)." Zootaxa 3459:1-156.

Jarnevich, C. S., M. A. Hayes, L. A. Fitzgerald, A. A. Yackel Adams, B. G. Falk, M. A. Collier, L. R. Bonewell, P. E. Klug, S. Naretto, and R. N. Reed. 2018. "Modeling the Distributions of Tegu Lizards in Native and Potential Invasive Ranges." Scientific reports 8 (1): 10193.

Klug, P. E., R. N. Reed, F. J. Mazzotti, M. A. McEachern, J. J. Vinci, K. K. Craven, and A. A. Yackel Adams. 2015. "The Influence of Disturbed Habitat on the Spatial Ecology of Argentine Black and White Tegu (Tupinambis merianae), a Recent Invader in the Everglades Ecosystem (Florida, USA)." Biological Invasions 17:1785-1797. 
Krysko, K. L., L. A. Somma, D. C. Smith, C. R. Gillette, D. Cueva, J. A. Wasilewski, K. M. Enge, et al. "New Verified Nonindigenous Amphibians and Reptiles in Florida through 2015, with a Summary of Over 152 Years of Introductions." IRCF Reptiles \& Amphibians 23:110-143.

Mazzotti, F. J., M. A. McEachern, M. R. Rochford, R. N. Reed, J. Ketterlin Eckles, J. J. Vinci, J. Edwards, and J. Wasilewski. 2014. "Tupinambis merianae as Nest Predators of Crocodilians and Turtles in Florida, USA.” Biological Invasions 17:47-50.

McEachern, M. A., A. A. Yackel Adams, P. E. Klug, L. A. Fitzgerald, and R. N. Reed. 2015. "Brumation of Introduced Tupinambis merianae (Squamata: Teiidae) in Southern Florida." Southeastern Naturalist 14 (2): 319-328.

Meshaka, W. E., Jr. 2011. "A Runaway Train in the Making: The Exotic Amphibians, Reptiles, Turtles, and Crocodilians of Florida. Monograph 1." Herpetological Conservation and Biology 6:1-101.

Offner, M.-T., T. S. Campbell,., and S. A. Johnson. 2021. "Diet of the Invasive Argentine Black and White Tegu in Central Florida." Southeastern Naturalist, 20(2), 319-337.

Pernas, T., D. J. Giardina, A. McKinley, A. Parns, and F. J. Mazzotti. 2012. "First Observations of Nesting by the Argentine Black and White Tegu, Tupinambis merianae, in South Florida." Southeastern Naturalist 11: 765-771.

\section{For More Information}

Contact Frank J. Mazzotti

UF/IFAS Fort Lauderdale Research \& Education Center

3205 College Ave., Davie, FL 33314

Email: fjma@ufl.edu

For more info, visit:

http://crocdoc.ifas.ufl.edu/

https://www.evergladescisma.org/ 